\title{
Reggae on the Silk Road: The Globalization of Uyghur Pop
}

\author{
Rachel Harris
}

\begin{abstract}
In this article I take examples of popular music recordings released in the Xinjiang Uyghur Autonomous Region during the 1990s and first few years of the 21st century, in order to illustrate the global flows of sounds and meanings which influence Uyghur pop. The disseminatory power of "micro media" (cheap cassettes, VCDs) facilitates the global movement of both musical sounds and political ideas. I argue, using examples of Uyghur reggae and Uyghur belly dancing, that these sounds and meanings are radically adapted and re-signified in the construction of Uyghur identity and cultural politics, in a complex interplay between the global, national and local, and between tradition and modernity. I discuss the gendered expression of Uyghur nationalism in popular song through the iconic figure of the weeping mother, demonstrating the ability of expressive culture (here music) to reveal underlying or underpinning political trends.
\end{abstract}

In recent years the notion of the Silk Road has enjoyed a new vogue, popularly invoked in a multiplicity of meanings revolving around the region of the former Soviet Central Asian States and China's Xinjiang Uyghur Autonomous Region. These range from the Silk Road Project led by celebrity cellist Yo Yo Ma creating remarkable fusion music from Mongolia to Azerbaijan, ${ }^{1}$ package tours transporting American and European citizens to Bukhara and Samarkand, to a 2004 British library exhibition $^{2}$ displaying the invaluable discoveries (or outrageous thefts according to your point of view) made by Sir Aurel Stein in the ruins of the ancient Buddhist kingdoms which lie beneath Xinjiang's Taklimakan desert. The most suitable evocation for the purposes of this article, however, is a photo article which appeared in the British Independent newspaper in 1998, which deftly illustrated the often surprising pathways of commodities under conditions of globalization on the contemporary Silk Road. ${ }^{3}$ The author, James von Leyden, drew readers' attention to the phenomenon of plastic bags advertising The Pet Shop, Pollokshaws Road, Glasgow, which at that time could be found in their millions all over the bazaars of Xinjiang. Contrary to rumour these plastic bags were not part of a container-load hijacked by mujahadin en route to Europe. Their presence in the Xinjiang bazaars was due to a loophole in international trading laws whereby manufacturers could obtain a subsidy if their products were found to be defective. Originally contracted by the Glasgow pet shop to produce 100,000 bags, the supplier in Xinjiang

1. http://www.silkroadproject.org/.

2. http://www.bl.uk/.

3. James von Leyden, "Plastic fantastic," Independent Saturday Magazine, 21 March 1998.

(C) The China Quarterly, 2005 
simply misprinted the telephone number, distributed tens of millions of the bags throughout the region, presumably claimed his subsidy and made a huge killing. As this article will demonstrate, musical sounds, captured in the commodity form of cassettes and CDs, travel by similarly diverse and surprising pathways into Xinjiang.

In his classic study of "cassette culture" in India, the ethnomusicologist Peter Manuel characterized cheap and easily reproducible new forms of technology, like the audio cassettes which spread around the globe in the 1970s, as "micro-media."4 Micro-media, he argued, stand for "decentralization, democratization and dispersal," providing potential channels for the expression and mediation of local identities, and are theoretically and politically opposed to the old mass-media. Micromedia's oppositional tendencies lie less in the content of the media than in their means of production. ${ }^{5}$ Manuel's dualist model of micro- versus mass-media risks over-simplification of the cultural and political complex surrounding recorded music. Nevertheless the concept of micro-media retains its usefulness, and there are numerous parallels between his detailed descriptions of cassette culture in India and the Uyghur scene where cassettes, and latterly VCDs, serve at national level (in the regional capital Ürüchi) as the medium for oppositional politics, and at local level (in smaller oasis towns and villages) to promote diverse and rarely heard subcultural sounds. ${ }^{6}$

The writings of Arjun Appadurai on globalization have informed my understanding of the ways in which global sounds enter and inhabit the sphere of Uyghur pop. Appadurai has suggested that processes of culture production in the changing spatial contexts of globalization have become primarily a question of identity politics, and that electronic media "transform the field of mass mediation because they offer new resources and new disciplines for the construction of the imagined selves and imagined worlds."7 I have argued in an earlier article that many themes expressed through Uyghur pop are bound up in issues of national or ethnic identity, which in Xinjiang are sharply political. ${ }^{8}$ In this article I take examples of popular cassette and VCD recordings released in the region during the last decade in order to illustrate the global flows of sounds and meanings which influence Uyghur pop. I argue that these sounds and meanings are radically adapted and re-signified in the construction of Uyghur identity and cultural politics, in a complex interplay between the global, national (here understood as the Uyghur nation) and the local, and between tradition and modernity.

4. Peter Manuel, Cassette Culture: Popular Music and Technology in Northern India (Chicago \& London: University of Chicago Press, 1993).

5. Ibid. pp. 1-2.

6. Mark Slobin, Subcultural Sounds: Micromusics of the West (Hanover \& London: Wesleyan University Press, 1993).

7. Arjun Appadurai, Modernity at Large: Cultural Dimensions of Globalization (Minneapolis \& London: University of Minnesota Press, 1996), p. 3.

8. Rachel Harris, "Cassettes, bazaars and saving the nation: the Uyghur music industry in Xinjiang, China," in T. Craig and R. King (eds.), Global Goes Local: Popular Culture in Asia (Vancouver: University of British Columbia Press, 2002), pp. 265-283. 


\section{A Brief Overview of Uyghur Pop Music}

Uyghur music-making traditionally revolves around the mäshräp (gathering or party) which draws the local community together for food, music and dancing. Weddings, circumcision parties, the major Islamic festivals and pilgrimages to saints' shrines are also important occasions for music. Singers are accompanied by the long-necked plucked and bowed lutes (tämbur, dutar and satar) and the dap frame drum, which are all found across Central Asia, often with the addition of the skirupka (violin, from the Russian) or accordion. Kettle drum and shawm bands (naghra-sunay) provide raucous, celebratory outdoors music. The singing style is highly ornamented, and the songs often employ the aqsaq or "limping" rhythms, which are also found in the rhythms of the Sufi zikr chants. Each oasis has its own distinctive musical style and repertoire, ranging from the more purely pentatonic sounds of the eastern town of Qumul (in Chinese Hami), to the modally more complex style of the old Silk Road town of Kashgar in the south-west. Historically, the local kings and elite of the different oases (such as Kashgar, Turpan, Khotan) patronized semiprofessional musicians who sang the prestigious Muqam suites. The term is derived from the Arabic maqām, but the style is local, indeed each of the major oases boasts its own unique Muqam tradition. Since the 1940s (before the incorporation of Xinjiang into the People's Republic of China) Uyghur traditions have been professionalized and modernized through the Soviet model of state-run performance troupes. Local traditions have formed the basis for new composition from revolutionary folk songs praising Chairman Mao to large-scale ensemble pieces and operas. To this day the troupes perform song-and-dance spectaculars celebrating the region's inclusion in the PRC. ${ }^{9}$

Commercially recorded music in Xinjiang has a rather short history, beginning in the 1980s when recording technologies, especially the cheap medium of cassettes and cassette recorders, became widely available. A visit to Döng Kövrük (in Chinese Erdaoqiao), the main bazaar in Ürümchi, reveals great diversity of music for sale. Most numerous are the locally-produced cassettes of Uyghur pop songs. More traditional-style cassette recordings can also be found: drum and shawm music from Turpan; instrumental dance music for weddings from Kashgar. Cheap VCD technology arrived in Xinjiang in around 1997, and now every music shop in the bazaar advertises its presence with televisions playing videos of the local pop stars, from the ever-popular actor-singer Abdulla Abdurehim to the briefly fashionable Madonna wannabe Aytelan.

Mainstream Uyghur pop marketed within Xinjiang has a wide audience, crossing the generational and the urban-rural divide, although the

9. For discussions of professional troupe performance in Xinjiang see Dru C. Gladney, "Representing nationality in China: refiguring majority/minority identities," Journal of Asian Studies, Vol. 53, No. 1 (1994), pp. 92-123; Rachel Harris, Singing the Village: Music Memory, and Ritual amongst the Sibe of Xinjiang (Oxford \& New York: Oxford University Press, 2004); Colin Mackerras, China's Minority Cultures: Identities and Integration since 1912 (New York: Longman Press, 1995); Sabine Trebinjac, Le Pouvoir en Chantant: l'art de fabriquer une Musique Chinoise (Nanterre: Société d'ethnologie, 2000). 
more obviously Western-influenced end of the market appeals mainly to urban youngsters. Pop music fills the schedules of Xinjiang's numerous Uyghur-language television channels. Pop singers perform live sets for dancing in high-class restaurants in Ürümchi. Cassettes of pop music fill the bazaars in smaller towns around the region. This broad appeal increases the opportunities for pop performers to disseminate new sounds and ideas. It is impossible to demarcate a clear line between traditional and pop in Uyghur recorded music. Most popular composers strive to maintain some local flavour in their songs. Continuity with tradition lies in the maintenance of traditional rhythms (though the drum machine renders these somewhat inflexible), the use of traditional instruments alongside the synthesizer, the adaptation of specific folk melodies, but especially in singing style and its communication of emotion. Traditional folk songs are frequently set to synthesized beats, regional traditions may be combined with electric guitar and drum set, and new songs are composed with traditional instrumental accompaniment, notably the dutar two-stringed lute.

Alongside the locally produced fare on sale in the Uyghur bazaars are numerous imports. Hindi films were the earliest foreign fashion to penetrate Xinjiang after the Cultural Revolution, following the early opening of the Pakistan border, and during the 1980s large crowds could be seen watching them on television in ice-cream stalls in the Kashgar bazaar, or in the pit-stop restaurants for long-distance travellers which line the desert roads. The variety of available sounds steadily increased through the 1990s with the opening of the borders with the Central Asian states, and greater access to Western sounds. By 2001 a hunt along the shelves of a music shop in Döng Kövrük bazaar might reveal the Sex Pistols' Never Mind the Bollocks alongside the Gipsy Kings, American country-and-western, Uzbek folk songs and Turkish pop. Inspired by this kind of diversity, the ethnomusicologist Philip Bohlmann has used the image of the Middle Eastern bazaar - with its capacity to collapse the boundaries of time and space, juxtaposing pop tapes and the imam's call to prayer - as a broad metaphor for folk music in the modern world. ${ }^{10}$ Although it is not my impression that the Sex Pistols have a big following in Xinjiang, and Uyghur musicians have yet to create their own brand of punk, the arrival of recordings like this into the region is interesting, and illustrative of the contemporary musical "Silk Road" on which it is situated. In spite of government attempts to crack down, the trade in pirate cassettes and VCDs flourishes. The dakou CDs, the subject of Jeroen de Kloets's article in this volume, also found their way to Ürümchi in the late 1990s, although here too they are now being superceded by the internet. Uyghurs benefit not only from the very successful Chinese bootlegging industry but also from pirate imports from Pakistan and the Central Asian states. If, as de Kloet argues, the spatial orientation of Beijing's rock scene lies between Hong Kong, Taiwan and the West, then

10. Philip Bohlman, The Study of Folk Music in the Modern World (Indiana University Press, 1988), p. 121. 
the Uyghur pop scene orients itself by a more diverse range of cultural influences emanating from Beijing, the West, India, Turkey, and the Central Asian states of Kazakhstan, Uzbekistan and Kyrgyzstan.

These diverse sounds are, of course, reproduced and incorporated into their own productions by Uyghur musicians. The earliest releases in the 1980s were dominated by the Russian-influenced waltz-style songs accompanied by the accordion which had first made their mark on the region in the 1950s. Heavy metal began to make inroads into the Uyghur urban youth market in the mid-1990s with the bands Täklimakan and Riwäyat; this kind of sound arrived in Xinjiang via the rock scene of Beijing. Popular flamenco guitar has been greatly in vogue since the mid-1990s. This sound has been incorporated into the Uyghur popular music repertoire by numerous Ürümchi-based singers and instrumentalists, and also by the Beijing-based cross-over star singer Äskär (lead singer of the band Hui Lang (Grey Wolf)) who sings both in his native Uyghur and, aiming at the wider market, in Chinese. ${ }^{11}$ Äskär has gained fans amongst educated young Uyghurs in Ürümchi who appreciate his experimental musical approach and higher quality production, but his lack of fluency in the Uyghur language and his orientation towards the Beijing rock scene distance him from the wider Uyghur audience.

The Uyghur pop market in Xinjiang also draws on the Uyghur communities in Turkey and across the border in the Central Asian states. One major cross-border success in recent years is the band Dervishes. ${ }^{12}$ Formed in July 1999 by four mainly Russian-speaking Uyghur musicians trained in the Almaty Conservatory, the Dervishes music is based in a heavy rock sound mixed with samples from Uyghur folk to Brazilian birembau and London clubland breakbeats. Mirroring Äskär they aim at the cross-over market, singing in a mixture of Russian and Uyghur. Well-known in their native Kazakhstan, they were also in 2003 the most popular band with urban youngsters in Xinjiang even though their music was only available in the region via bootleg recordings. It is telling that the two bands most popular with fashionable youngsters in Ürümchi are both based outside the Uyghur region and neither is at home with the Uyghur tongue. Uyghur musicians working in Beijing and Almaty, especially those educated in the Chinese or Russian language, have greater access to new musical sounds and quality recording equipment, and they best represent for the increasingly outward-oriented urban youngsters the desired combination of modernity and self.

Musical sounds also flow out of the region. In Kazakhstan, where there is a population of some half a million Uyghurs, there is a fairly substantial market in bootleg copies of cassettes released by Xinjiang artists, their covers re-worked to include the Uyghur titles in the Cyrillic lettering employed in the former Soviet states. Uyghur pop music can be

11. Äskär, Tiläg (Blessing) (China: DMVE Co., 2001). Cf. Nimrod Baranovitch, "Between alterity and identity: new voices of minority people in China," Modern China, Vol. 27, No. 3 (2001), pp. 359-401.

12. Dervishi, Dunya (World) (Kazakhstan: Ala Music Enterprises, 2002). Official website: www.show-kz.com/dervishi. 
downloaded from several websites maintained by the exiled community in the United States, most of which carry a strong political agenda. ${ }^{13}$ Han Chinese pop singers have also drawn on the "exotic" sounds of traditional Uyghur music to infuse their own productions, from the perenially popular songs of the revolutionary era song-writer Wang Luobin ${ }^{14}$ to the most recent hit singer, Sichuan-born "Daolang" (whose name is borrowed from the Dolan Uyghurs of the Tarim river), whose songs include rock-style reworkings of revolutionary classics with Uyghur instrumental backing. ${ }^{15}$

\section{Reggae Re-signified}

A closer analysis of two popular songs and their accompanying videos from the mid-1990s serves to illustrate some of the complexities of Uyghur musicians' appropriation of global sounds, and the extraordinary mutability of these sounds and their meanings under conditions of globalization. The ethnomusicologist Veit Erlmann has described the phenomenon of World Music as one of the disjuncture of sounds and meanings. Musical sounds, captured on recording medium and separated from their original sources and contexts, are disembodied. As these disembodied sounds circulate around the globe with increasing ease and rapidity, on cassettes, via broadcast media and over the internet, their meanings are detached and their sounds are re-signified. Erlmann explores how listeners shift the contexts of their knowledge and endow phenomena with significance beyond their immediate realm of personal experience. He suggests, adapting Appadurai's theories of globalization, that World Music invents realities generated by electronic means. Sense manufactured in this way out of discontinuities, he argues, is arbitrary and rampant, and can no longer mediate culture-specific processes of appropriation of the external world; it is neutral ground. ${ }^{16}$ These two contrasting, even opposed, examples of musical appropriation illustrate how facets of Uyghur identity are constructed through music from such apparently arbitrary discontinuities.

The first example is a reggae version of a Khotän folk song titled "Qatlima" performed by the singer-guitarist Shiräli. Released in 1995 and a big hit in Ürümchi, this song juxtaposes a reggae bass beat with the lyrics and melody of a popular Uyghur folk song infused with the images and smells of home; qatlima is a type of flat bread stuffed with meat and onions commonly baked by Uyghur women in the family home.

13. Clearly, the songs of artists working within the PRC appear on such websites without the knowledge or permission of the artists. See for example http://www.uyghuramerican.org/ uyghurche/muzika/ or http://www.meshrep.com/.

14. Cf. Rachel Harris, "Wang Luobin: folksong king of the northwest or song thief? Copyright, representation and Chinese folksongs," Modern China, Vol. 31, No. 3 (2005), pp. 381-408.

15. http://www.esee.cn/daolang.htm.

16. Veit Erlmann, Music, Modernity and the Global Imagination: South Africa and the West (Oxford: Oxford University Press, 1999), pp. 187-88. 
"Qatlima" Shiräli; trad. ${ }^{17}$

Qatlimayu qatlima

Käng eriqtin atlima

Kelishinggä chay tutay

Yenishinggha qatlima

Oti yaman nakhshamning

Nawasi bu akhshamning

Anglap qanmaymän dimä

Mänggu bu küylär sening ...
Qatlima oh qatlima

Don't jump over a wide stream

When you come I'll give you tea

When you leave, qatlima

My song burns powerfully

Joy this evening

Don't say you can't get enough

These tunes are forever yours ...

It would be tempting to attribute the appropriation of reggae by Uyghur musicians to a desire to identify with Black Jamaicans as another subaltern minority, but the imagery of the accompanying video suggests that such an identification is far from Shiräli's mind. In the video he appears dressed in cowboy boots and hat, sitting contemplatively guitar in hand on a rock in the middle of the desert. The reggae sounds are subsumed into classic American imaginings of the cowboy and the Wild West. A Uyghur reggae cowboy? Even Shiräli's appropriation of the cowboy imagery owes much to Chinese imaginings of Xinjiang as its own Wild West, as recently reproduced in the martial arts blockbuster Crouching Tiger, Hidden Dragon, or as promoted within the Xinjing region through television advertisements for the powerful local brand of alcohol Yili Tequ. But Shiräli is clearly not content to play the Red Indian to the Han Chinese, to be always the Other in Chinese imaginings; he situates himself centrally in his own re-imagining of the American fantasy.

America is not the only object of Uyghur imagining. Another popular Uyghur disco-style release in 1999 featured a remarkable song entitled "Bälli." The term in Uyghur means not "belly" but literally "good, well done!" but its link to belly dancing was clearly underlined by the accompanying video. Belly dancing is not a traditional Uyghur art although it features strongly in Chinese popular culture's imaginings of the region's "exotic" Muslim women, and is promoted for Han and foreign eyes in floor shows in upmarket Uyghur restaurants in Beijing. ${ }^{18}$ It is hard to say if the fashion for belly dancing in Ürümchi has come indirectly from such sources or more directly from the Arab world, which has in recent years become a source of inspiration for young Uyghurs. Musical sounds flow into Xinjiang from Saudi Arabia in the form of cassette recordings of Qur'anic recitation which are popular gifts to bring back from the hajj. ${ }^{19}$ Also highlighted in official reports is the flow of Wahabbi or fundamentalist propaganda smuggled into the region in video form. ${ }^{20}$ Arab states like Saudi Arabia and Syria may be regarded

17. Shiräli, "Qatlima," Tarim (China: Xinjiang Nationalities Recording Co., 2000).

18. Nimrod Baranovitch, "From the margins to the centre: the Uyghur challenge in Beijing," The China Quarterly, No. 175 (2003), pp. 726-750.

19. Although according to Muslim belief Qur'anic recitation is not properly regarded as music.

20. I have not personally seen any such videos, although I have come across a few videos smuggled into the region from the Central Asian states carrying Christian propaganda. 
by the authorities as sources of fundamentalist propaganda and violence, but they are more often regarded by Uyghurs as rich, modern and Muslim, offering alternative models of development for Uyghur society to those promoted by the Chinese state. Orthodox models of Islam emanating from these states have attracted numbers of followers across Xinjiang. Both the full black all-over body covering of the hijab adopted by some Uyghur women returning from the hajj and belly dancing are in vogue in Ürümchi. ${ }^{21}$

\section{“Mother's White Milk”}

Throughout the 1990s, as political tensions increased, the Xinjiang authorities have frequently claimed that malign outside forces are instrumental in spreading separatism in the region, and more recently they have used the global war on terror to reinforce these claims. Following September 11 the authorities have pursued a comprehensive propaganda campaign on the domestic and international front to label all Uyghur opposition, peaceful or violent, as linked to international terrorist networks. The Xinjiang media have carried explicit warnings against the use of micro-media, especially audio and video recordings used to promote religious fanaticism or jihad, and also against popular cultural activities conducted within the region which might be used to encourage opposition. ${ }^{22}$ Although productions like "Bälli" have not as yet been considered as oppositional by the authorities, other styles of popular music have been targeted. Several writers working on Uyghur culture and politics have previously drawn attention to the use of veiled metaphors and allusions in the realm of popular song lyrics to reference political undercurrents which cannot be raised in more direct ways. ${ }^{23}$ Since the mid-1990s the Xinjiang authorities have become increasingly sensitive to these and increasingly active in suppressing them, but in the postSeptember 11 period they have been explicitly equated by the authorities with separatism and with Islamic terrorism. This tightening of state control over cultural production in Xinjiang is in direct contrast to the relaxation of controls in inner China since 1997.

The blanket equation of opposition to Chinese rule with global political currents and outside forces is misleading, at least in the field of popular culture, since it is the group of singers whose musical sounds are least

21. See Rudelson and Jankowiack's discussion of alternating "soft-hard" government policies towards local Islam and Uyghur contacts with other parts of the Islamic world: Justin John Rudelson and William Jankowiack, "Acculturation and resistance: Xinjiang identities in flux," in Frederick Starr (ed.), Xinjiang: China's Muslim Borderland (New York \& London: M. E. Sharpe, 2004), p. 301.

22. Nicolas Becquelin, "Criminalizing ethnicity: political repression in Xinjiang," China Rights Forum, No. 1 (2004), pp. 39-46.

23. Gardner Bovingdon, "The not-so-silent majority: Uyghur resistance to Han rule in Xinjiang," Modern China, Vol. 28, No. 1 (2002), pp. 39-78; Harris, "Cassettes, bazaars and saving the nation," pp. 265-283; Joanne Smith, "Barren chickens, stray dogs, fake immortals and thieves: coloniser and collaborator in popular Uyghur song and the quest for national unity," in Ian Biddle and Vanessa Knights (eds.), Music, National Identity and the Politics of Location: Between the Global and the Local (Aldershot: Ashgate, forthcoming). 
outward-looking, and whose verbal messages are most bound up with the core concerns of the Uyghur community, who have been most powerful in their expressions of dissatisfaction and most consistently in conflict with the authorities. These singers exemplify the position that some composers and singers occupy in the Uyghur community: one of moral leadership. They perform traditional-style songs set to contemporary lyrics, accompanying themselves on the Uyghur dutar two-stringed lute. The best known of these singer-dutarists is Ömärjan Alim from the northern town of Ghulja (in Chinese Yining). A discussion of two of his songs - "Anamni äsläp" ("Remembering mother") ${ }^{24}$ released in 1994 and "Kättingiz ana" ("Mother, you have gone") ${ }^{25}$ released in 2000 - reveals much about changing attitudes amongst Uyghurs to their political predicament. The songs also reveal, through their musical sounds and their lyrics, the tension between tradition and modernity which informs the constructions of national identity by Uyghur intellectuals, and they show how such tensions are expressed in gendered form.

In terms of discourses of gender revealed through Uyghur song lyrics, male desire is the most common theme, typically expressed in terms of burning fire, suffering and pain. Man is the ashiq, the pursuer, inflamed by unfulfilled passion, and woman the mäshuq, the object of desire, the pursued, who cruelly withholds herself from the suffering lover. In contrast to this established rhetoric of desire, another image of femininity frequently emerges in Uyghur song: the figure of the idealized mother, invariably depicted as careworn, weeping, nurturing, self-sacrificing. As if in flight from the rhetoric of fire, male singers seem to escape to the comforting figure of mother. In Uyghur songs, in contrast to the flames of romantic love, the mother is essentially wet with flowing tears and white milk, and she is a key signifier in the rhetoric of sentimentality and pathos. This iconic mother figure is often evoked in traditional lyrics, but in contemporary Uyghur pop we find an added layer to the discourse on mother love. Abdumijit Dölätov, a Kazakhstan-based journalist and well-known poet and lyricist for singers on both sides of the border including the Dervishes, is an enthusiastic user of the Mother allegory. In an interview in 2003 he responded to a question on this preference with a political manifesto:

Mother means country, flag, motherland .... Mother is all we have. We are an oppressed people, but the one thing you can't take away from people's hearts is mother, no power can stop mother love. ${ }^{26}$

The "motherland" in question, need it be said, is not the Chinese "zuguo" but East Turkistan, as Uyghurs outside the region commonly term Xinjiang. The notion of Mother as central icon in the nationalist agenda has, of course, precedent in popular cultural representations around the

24. Ömärjan Alim, "Anamni äsläp" ("Remembering mother”), Pärwayim peläk (Destiny Is My Concern), confiscated: no publishing details, 1994.

25. Ömärjan Alim, "Kättingiz ana" ("Mother, you have gone”), Tarim (China: Xinjiang Nationalities Recording Co., 2000).

26. Interview, Almaty, July 2003. 
world. In Hindi films, once very popular in Xinjiang, we find central to numerous plots the archetypal and usually embattled figure of Mother who embodies good, tradition and Indian-ness, and whose suffering and eventual triumph provokes strong emotions. ${ }^{27}$ Similarly Rey Chow has discussed the use of sentimentalism in 20th-century Chinese literature, writing of a masochistic identification with the fictional Other, where pain and sacrifice are intrinsically maternal and directly equated to political or cultural crisis. ${ }^{28}$ The clearest and most emotive expression of this allegory in Uyghur song was voiced by Ömärjan Alim in his mid-1990s song "Anamni äsläp," a lament for mother. Her death clearly symbolizes the death of the nation, and alongside the forceful expression of grief, we can hear a call for vengeance.

“Amamni äsläp” ("Remembering mother”) Ömärjan Alim

Köptin beri chushum buzulup

Ötär idi ghäshliktä künüm

Bügün mana shum hävär kilip

Chüshüp ketti ichimgä ünüm

Ana shundaq yärgä kettipsiz

Ana disäm "hä" dimäydighan

Män qaldim bek eghir azapqa

Äsläp tolghunup häsrät ...

äy ... häsrät yäydighan

Bu häsrätni kimdin alimän?

$B u$ därdimni kimdin alimän?

Täqdir shundaq bulghachqa

Mänmu shundaq dimäy qandaq ... äy ...qandaq qilimän
For a long time I've had bad dreams

I pass my days depressed

See, today bad news has come

Words fail me

Mother you went to that place

I call mother, no one answers

Heavy suffering has come upon me Remembering I am sick with grief ah ... I have eaten grief

Who will I make pay for this grief? Who will I make pay for this pain? Destiny has turned out like this And so I will not ask what... ah ... what should I do

This song was released in 1994 at the height of Ömärjan's popularity. At that time his cassettes formed a constant soundtrack to the bustle of Döng Kövrük bazaar in Ürümchi, blaring from every cassette stall and restaurant. His songs with their brilliant dutar accompaniment and popular style of language, "earthy" as one Uyghur recording engineer put it, also enjoyed unprecedented sales in rural areas. ${ }^{29}$ This musical sound, which I described above as "traditional-style," might be better termed a 1990s revival or rather a reinvention of tradition in the sphere of popular culture. In the 1980s, as mentioned above, the dominant style in popular song was the Russian waltz, and traditional Uyghur instruments rarely featured in popular music. The mid-1990s rise of the dutar-singers was a response to a perceived need for an authentically Uyghur popular music.

27. Rosie Thomas, "Melodrama and the negotiation of morality in mainstream Hindi film," in C. Breckenbridge (ed.), Consuming Modernity: Public Culture in a South Asian World (Minneapolis \& Oxford: University of Minnesota Press, 1995), pp. 157-182.

28. Rey Chow, Woman and Chinese Modernity: The Politics of Reading between West and East (Minneapolis \& Oxford: University of Minnesota Press, 1990).

29. See Harris, "Cassettes, bazaars and saving the nation" for a fuller transcript of this interview. 
Based on traditional styles of dutar performance, Ömärjan's songs are nevertheless newly composed and deviate from tradition in a number of ways. The bass register of the voice and typically minor feel of the melodies owe more to Western influence than to traditional Uyghur vocal style and modality. Most significantly, this style is not attributable to any one oasis town; it establishes a pan-Uyghur national style which transcends or overlays local traditions, thus increasing the songs' popularity and ability to disseminate political messages.

“Anamni äsläp" was one of Ömärjan's most emotive and radical calls to arms. Its release was probably made possible only because it was produced by a Chinese recording company based in Guangzhou, thus evading the scrutiny of the censor in Xinjiang. In the early 1990s, Uyghur musicians had taken advantage of the burgeoning free market in China to strike recording deals with newly established independent Chinese recording companies from Shanghai to Guangzhou. In the year following the release of "Anamni äsläp" the Xinjiang authorities were already beginning their "crackdown on the cultural market," and it was becoming increasingly difficult to reference Uyghur discontent in the public forum, even through such veiled allegories. After 1995, such out-of-town deals were restricted, and Uyghur language music cassettes and VCDs were only permitted if released by the state-owned Xinjiang Nationalities Recording Company or the Beijing-based Nationalities Recording Company which kept a much tighter rein on the lyrical content of Uyghur cassettes.

Whilst the direct political messages of Ömärjan's most famous songs faded from the forum of popular song into the late 1990s, as a direct result of tighter government control, the number of laments for the death of a loved one in the guise of popular songs has noticeably increased. In the aftermath of 1997 and the brutal suppression of the February demonstrations in Ghulja, ${ }^{30}$ it seemed that the Uyghurs had more to grieve about both politically and literally, and these personal laments in the public sphere of pop, without referencing the sphere of public action, were nevertheless expressing a popular grief for which there were few other outlets. In 2001 when I returned to Ürümchi I again met the recording engineer who a few years previously had enthusiastically unpicked for me the political ramifications of Ömärjan's songs. "Things aren't like that any more," he told me, "we were young then. Now we just think practically about how to get our kids to study abroad." 31 This remark was typical of a new mood amongst Ürümchi intellectuals, most of whom had replaced the nationalism of the mid-1990s with an increasingly pragmatic and global outlook.

The muting of nationalist sentiment also had its expression in popular song. In the year 2000 Ömärjan Alim released a new lament for mother. Musically this is a close echo of the earlier "Anamni äsläp," transposing 
and developing the same melodic material, but in terms of performance style and lyrics a very different mood is expressed. Here again is grief, but it is accompanied not by anger but rather by resignation and nostalgia. The actor in the accompanying video traces a journey from modernity working at his computer, travelling along the newly built highway - back to the impoverished Uyghur village. Such images typify the experience of Ürümchi-based Uyghur intellectuals. Distanced but emotionally entangled, educated and working in the Chinese-dominated city but brought up in the Uyghur village, the actor makes the long journey from urban modernity returning to rural home, his mother's funeral, and memories of an idealized youth dominated by a caring and inevitably weeping mother. Under conditions of globalization we typically find women positioned as repositories of tradition, a position which inevitably carries an emotional burden, and here "Mother, you have gone" references the singer's complex emotional relationship as urban intellectual with his rural roots, where the mother figure is emblematic not only of nation but also of tradition. What is mourned, it seems, is not only the fading national dream but also the passing of a way of life.

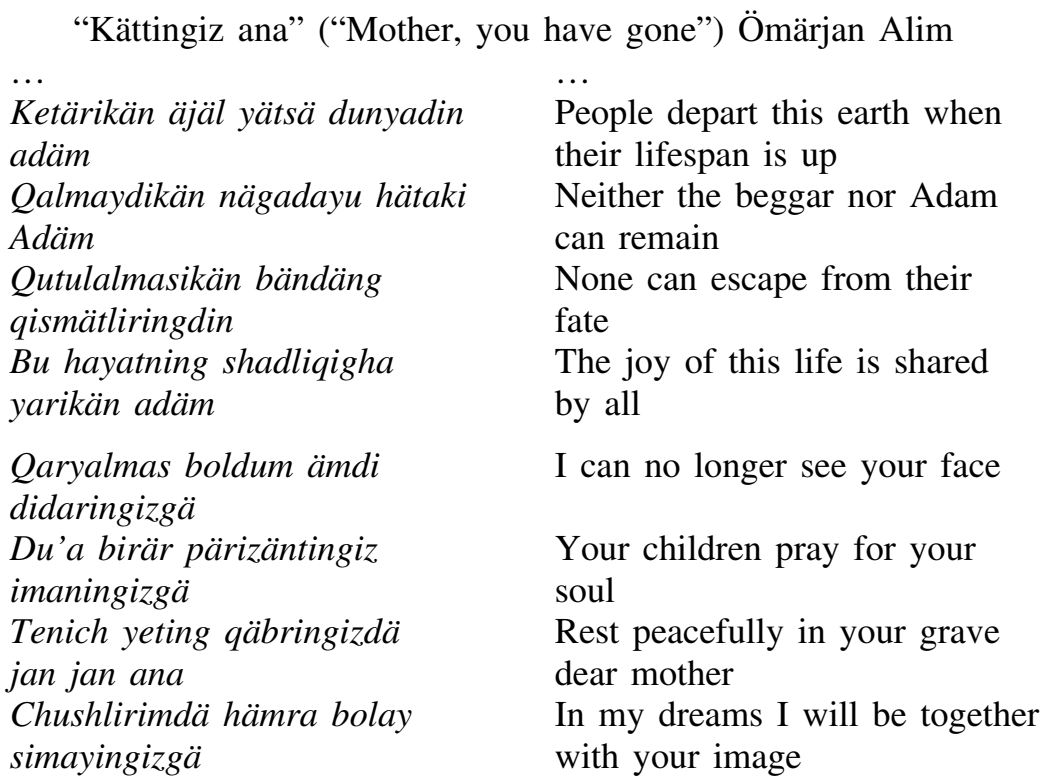

Situating the Harem Garden in Guangzhou

Thus far I have been concerned with Uyghur music and identity politics at national level. Much has been written about the formalization of minority national identities in China, and how they overlay a more complex reality of local, religious and clan allegiances. ${ }^{32}$ The reality

32. Dru C. Gladney, "The ethnogenesis of the Uighur," Central Asian Survey, Vol. 9, No. 1 (1990), pp. 1-28; Stevan Harrell, "Introduction: civilising projects and the reaction to them," in S. Harrell (ed.), Cultural Encounters on China's Ethnic Frontiers (Seattle: University of Washington Press, 1995), pp. 3-36; Justin John Rudelson, Oasis Identities: Uyghur Nationalism along China's Silk Road (New York: Columbia University Press, 1997). 
underlying the modern concept of "Uyghur music" also displays this kind of diversity. Each oasis town within Xinjiang possesses its own distinctive musical repertoire and style, the Kashgar uslub (style) or the Khotan puraq (flavour). Local singing style is said to relate to the local dialect, the local environment, even the local character. Certain instruments are found only in one oasis while others are more widespread. Within a single oasis region individual villages may also have their own repertoire of songs or dance suites. Access to rural areas in Xinjiang is not always easy for foreign researchers, ${ }^{33}$ but it is of great interest to move beyond the bazaars and the urban spaces inhabited by pop musicians to look at the impact of technology and globalization at local level. What impact are the marketing of global sounds and the production of new popular styles at national level having on contexts of music-making in the oasis villages of Xinjiang? And how are musicians at local level themselves making use of micro-media?

In the small oasis town of Yarkand in southern Xinjiang there is a run of cassette stalls in the dusty back street bazaar. Each one displays several hundred cassettes, mainly Uyghur pop with a few imports from Uzbekistan and India. Here all concessions to copyright have disappeared. The stall owners possess one copy of each cassette, and run off copies to order on the copy machine prominently displayed on the counter. These are sold for about five yuan, half the price of the originals available in larger towns. Inevitably quality deteriorates with each copy made; customers take their luck. Also for sale, if you know to ask, held under the counter are boxes full of locally made recordings, not produced or packaged in any way but simply copied on to cassette and marked with fading biro. These cassettes include live recordings of local singers made at mäshräp parties and a few recordings of ritual music, local Sufi orders performing the ritual zikr at shrine festivals. ${ }^{34}$ At this level of the market, where these most local of sounds are transformed into commodities and sold alongside the Ürümchi pop singers, Peter Manuel's theories of technology and hegemony and the role of micro-media in reinforcing and revitalizing local traditions and styles are most applicable. ${ }^{35}$

Yarkand's favourite mäshräp singer in 2001 was Änwärjan who, like Ömärjan Alim, plays the dutar two-stringed lute; a 20-year-old layabout, according to a local taxi driver who was playing one of Änwärjan's cassettes in his car, who does nothing but play at mäshräp, but an undeniable talent. Änwärjan sings in an, to Ürümchi ears, old-fashioned, high-pitched, boyish vocal style which professional singers have cast off in favour of an operatic booming bass. The dutar style is typical of this part of southern Xinjiang, the fast $3+3+2$ beat underlying the four-beat of the sung melody, the instrument tuned in fourths rather than the more

33. Harris, Singing the Village, pp. $\mathrm{xv}-\mathrm{xx}$.

34. Cf. Rachel Harris and Rahilä Dawut, "Mazar festivals of the Uyghurs: music, Islam and the Chinese state," British Journal of Ethnomusicology, Vol. 11, No. 1, pp. 101-118. 35. Manuel, Cassette Culture, p. 129. 
common fifths, and pitched to suit Änwärjan's voice almost a fifth higher than is common in Ürümchi. The cassettes are recorded live at mäshräps and include songs which have been current in this area for several decades, mainly comic and combative love songs using the folk beyit poetical form, rich in metaphors and allusions. Yet these cassettes are not recordings of frozen traditions. Like the other pop songs discussed, Änwärjan's songs also reflect and enact contemporary social conditions, but they make an interesting contrast to the songs discussed above. Whereas Shiräli in his reggae-style folk song employed homely lyrics juxtaposed with global sounds, Änwärjan's musical sound is local while his lyrics reach outwards. Also striking at this level is how much less evident the nationalist impulse is. In contrast with the nostalgic homeward journey undertaken by Ömärjan Alim, Änwärjan's lyrics transport him in progressive stages to destinations outside his local region, reproducing the journeys made by Uyghur rural migrants as, impelled by rural poverty and under-employment, they move to the major towns of Xinjiang in search of jobs or business opportunities, and then "inside the mouth" of the Gansu corridor (kouli), eastwards to the cities of central China. ${ }^{36}$

\section{"Shokh dutar" ("Naughty dutar") Änwärjan}

Yarimning qara sachi

Ashiptu zinga qigä

Khäqning yarni yayrim däp

Öläymu taya qigä?

Oynayli häräm baghda

Bushä Yengishä aldida

Chidimay qalisiz u chaghda

Oynayli Mäkitä

Qonashä Yengishä aldida

Marab qalisiz daldida

Bizning balilar yaman balilar

Oyanchi yaman balilar

Bizni yaman digänlär

Ghajaydu quruq kallar ...

Oynayli häräm baghda

Ärdawchawda Guwangjuda

Chidimay qalisiz u chaghda
My darling's black hair

Reaches down to her nape

If I call another's lover darling

Will I be beaten to death?

Let's play in the palace garden In the town by the new town You won't be able to stand it then

Let's play in Mäkit

In the old town in the new town You'll sneak a look behind you

Our boys are tough boys

Good time tough boys

They say we're bad

They're gnawing an empty skull

Let's play in the palace garden In Erdaoqiao, in Guangzhou

You won't be able to stand it then

36. Nicolas Becquelin notes that in southern Xinjiang incomes rest at half of the provincial average, rural under-employment is acute, and up to $45 \%$ of the Uyghur population have migrated to towns where they face great difficulties in finding employment; Nicolas Becquelin, "Staged development in Xinjiang," The China Quarterly, No. 178 (2004), p. 372. 


\section{The Troublesome Tämbür Technique of Nurmuhämmät Tursun}

Also prominent in the display of cassettes in the Yarkand stall are several recordings by one of Xinjiang's most famous tämbür lute players, Nurmuhämmät Tursun. Nur was employed by the Xinjiang song-anddance troupe in Ürümchi until 2001 when he fell foul of the authorities due to his involvement in a New Year concert at which a "separatist incident" occurred. ${ }^{37}$ Although he lost his status within the troupe and was banned from travelling abroad, Nur was able to continue his career as one of Xinjiang's most prominent recording instrumentalists until his untimely death in December $2004 .{ }^{38}$ He was widely regarded as the finest tämbür player in the region, with brilliant technique and a wide repertoire of folk and classical pieces. He was also known for his exploration of new repertoires and his innovative style of playing which encapsulates the ideology of the virtuoso, star performer promoted by the pop music industry. Key aspects of his style include his use of fast riffs and high pitch, and an almost romantic interpretation of the melody, with flexible use of rhythm and prominent vibrato.

Nur's last CD release (an unusual format in Xinjiang) Kün wä tün (Day and Night $)^{39}$ is his most experimental, an extraordinary confection which juxtaposes a medley of popular Spanish tunes ${ }^{40}$ with a Pakistani film song dubbed into Uyghur as "Mängülük muhäbbät" ("Never-ending love") which was popular in the region in the 1980s. Alongside these renditions of global melodies performed on the tämbür is a radical reinterpretation of a piece at the heart of the classical Uyghur repertoire, "Äjäm." 41 Western purists might find the lush harmonies added by synthesizer the most jarring aspect of this interpretation, but what upsets traditionally minded Uyghur musicians about this is something quite different.

The tämbür lute has five metal strings arranged in three courses. The melody is generally played on the highest single string, while the other two paired strings are struck only as drones, punctuating the melody. Nur introduced an original and idiosyncratic strumming of all three courses of stopped strings simultaneously, producing tuned chords. This small innovation produced a disproportionate degree of controversy within Uyghur music circles, in part because he employed it in "classical" pieces like "Äjäm" and the iconic Twelve Muqam suites, and in part simply because of his great influence on young players. Nur had many followers around the region who learned the new style from his cassettes and who have begun to replicate the style on their own cassette recordings. This is the

37. See Becquelin, "Criminalizing ethnicity," for further details.

38. Nurmuhämmät Tursun died on 18 December 2004, aged 47 of a heart attack. Obituaries (in Uyghur) and downloads of his music can be found on the Radio Free Asia Uyghur language website: http://www.rfa.org/uyghur/xewerler/tepsili_xewer/2004/12/20/ nurmuhemmet-tursun/.

39. Nurmuhämmät Tursun, Kün wä tün (Day and Night) (China: Nationalities Recording Co., 2003).

40. Most prominently "España cañi” by composer Pascual Marquina.

41. A more orthodox rendition of this piece can be heard on: Music from the Oasis Towns of Central Asia. Uyghur Musicians of Xinjiang (London: Globestyle, 2000). 
new wave, and it now spreads right across the region. The sometimes bizarre debate which Nur's techniques have provoked illustrates some of the anxieties surrounding Uyghur culture and identity, and it evokes again Veit Erlmann's remarks on the disjuncture of sounds and meanings in global flows of musical sounds and technology. ${ }^{42}$

A Kazakhstan-based Uyghur musicologist with whom I spoke in 2001 was horrified on hearing an example of Nur's new style. "This is how Uyghur music is being infected with Chinese influence these days!" she exclaimed, "he's playing the tämbür like the Chinese pipa." "43 This remark was revealing of a politically and musically defensive attitude (not to say a lack of familiarity with pipa technique) which is commonly found amongst minority groups who perceive their culture and identity to be threatened by assimilation into the larger culture, where any kind of musical innovation is heard as deviation from authenticity and evidence of the encroaching influence of the other culture. The ethnomusicologist Keila Diehl, in her study of Tibetan exile music in Dharamsala, describes an equivalent attitude amongst that highly politicized community which is striking for the vehemence in which it is expressed. Dharamsala musicians situate themselves as preservers of the authentic musical traditions of the Tibetan homeland, which they regard as threatened by Chinese influence. They describe in terms of powerful vitriol the Chinese pollution of their music over 50 years of Chinese rule. ${ }^{44}$ As with the Kazakhstan-based Uyghur musicologist, such attitudes are typically expressed by voices from the diaspora who are distanced from the musical changes which occur within the culture. In fact Uyghur musicians within Xinjiang are equally as disapproving of Nur's new style, but less likely to attribute the polluting factor to the Chinese. They, and Nur himself, have acknowledged that the new technique is due less to the pernicious influence of Chinese music than to popular flamenco guitar, in particular the Gipsy Kings cassettes which took Xinjiang by storm in the mid1990s. It is a feature of the patterns of globalization and Uyghur identity politics that musicians in Ürümchi are more exposed to, and open to, the sounds of popular flamenco than to the Chinese pipa.

\section{Conclusion}

In this article I have attempted to recast the idea of the Silk Road as cultural conduit for musical sounds and meanings under conditions of globalization, describing an electronic "Silk Road" whose routes have less to do with geographical contiguity than with Uyghur musicians' search for self. I have highlighted a few examples of recorded music to illustrate questions of change and continuity in musical practice in Xinjiang in a period of rapidly expanding access and exposure to outside

42. Erlmann, Music, Modernity and the Global Imagination, pp. 187-88.

43. Tamara Alibakieva, interview, Washington DC, July 2002.

44. Keila Diehl, Echoes from Dharamsala: Music in the Life of a Tibetan Refugee Community (Berkeley, London, Los Angeles: University of California Press, 2002). 
influences. These examples show how questions of identity interact with global flows of musical sounds, where certain outside sounds are briefly adopted wholesale but their meanings are subtly altered, and where aspects of global styles are brought into the heart of the traditional repertoire. They demonstrate the ability of micro-media to embody and respond to changing social identities, providing new possibilities for musical and socio-political discourse, although the expressions which emerge through these media are often conflicting and ambiguous. I have tried to highlight the often neglected question of reception and impact on musical life of the broader population outside the urban centres where mainstream recording artists are active, showing how locally produced sounds sit side-by-side with examples of the national style in small town cassette stalls. Equally the role of the individual musician cannot be overlooked in discussions of interactions between the global and the local. Veit Erlmann claims the very idea of locality is a problem, describing "a strange dialectic of the near and far, local and global" where "the making of individual experience may well happen in one place, while its actual coordinates lie in a reality beyond the limited, local space." 45 While young tämbür players in Yarkand who pick up the new style from Nur's cassettes may not be aware of their debt to the Gipsy Kings they are certainly aware of the possibilities, and a new verse may easily be added to Änwärjan's song placing the harem garden in New York or perhaps in Saudi Arabia. 